УДК 549:553.493.66(571.151)

\title{
ИТТРИЕВЫЕ РЕДКОЗЕМЕЛЬНЫЕ И РЕДКОМЕТАЛЛЬНЫЕ АКЦЕССОРНЫЕ МИНЕРАЛЫ ЛЕЙКОГРАНИТОВ АЛЕЙСКО-ЗМЕИНОГОРСКОГО КОМПЛЕКСА (РУДНЫЙ АЛТАЙ)
}

\author{
Новоселов Константин Леонидович, \\ novoselov@tpu.ru \\ Национальный исследовательский Томский политехнический университет, \\ Россия, 634050, г. Томск, пр. Ленина, 30.
}

\begin{abstract}
Актуальность и цель исследования. Изучением гранитоидов алейско-змеиногорского комплекса впервые установлено в единичной пробе лейкогранитов четвёртой фразы внедрения присутствие редких акцессорных минералов иттрия (nриорит, фергюсонит), генезис которых, по существующим данным, пегматитовый, пневматолито-гидротермально метасоматический, но формирование их на магматическом этапе становления интрузии считается наименее типичным. Цель работы состоит в выяснении условий генезиса приорита, фергюсонита в алейско-змеиногорских лейкогранитах. Кроме того, требует решения вопрос источника иттрия и сопутствующих редкоземельных элементов лишь на единственном участке внедрения пород.

Методы исследования включают традиционные минералого-петрографические исследования, выделение акцессорных минералов и изучение их видового состава в искусственных протолочках, начальный вес которых составлял 5...8 ке; аналитические исследования минералов выполнены в Институте геологии и минералогии СО РАН (2. Новосибирск) на электронном сканирующем микроскопе JSM-6510LV (Jeol Ltd) с энергодисперсионным спектрометром INCA Energy 350+ (аналитик мл. науч. comp. М.В. Хлестов) и на рентгено-фрлюоресцентном микроскопе (отделение геологии Инженерной школы природных ресурсов ТПУ, аналитик канд. геол.-минерерал. наук М.А. Рудмин).

Результаты. Впервые в гранитоидах алейско-змеиногорского комплекса встречен комплекс редких акцессорных минералов иттрий-ниобиевого, иттрий-титанового состава наряду с ранее отмечавшимися минералами иттрия (ксенотим), редкоземельным монацитом, ниобатами (колумбит, ильменорутил).

Выводы. Присутствие приорита и фергюсонита в единичном штоке лейкогранитов IV интрузивной фазы позволяет рассматривать данный шток как результат деятельности длительно существовавшего канала поступления вещества последовательных фраз внедрения интрузии. Вероятно, свободное поступление материала из первичного магматического очага стало благоприятным фактором для насыщения пород данного участка иттрием, РЗЭ, редкими металлами. Выделение акиессорных минералов соответствующего состава произошло на завершающей стадии формирования интрузива в результате автометасоматоза апикальной и краевых частей.
\end{abstract}

\section{Ключевые слова:}

Рудный Алтай, гранитоиды, акцессорные минералы, приорит, фергюсонит, ксенотим, торит, торианит, монацит.

\section{Введение}

Алейско-змеиногорский комплекс $\left(\mathrm{D}_{2-3}\right)$ включает три крупных гранитоидных массива - Новониколаевский, Алейский, Устьянский, и ряд более мелких тел, локализованных в структурах северной части Алейского поднятия Рудного Алтая [1]. Наибольшую

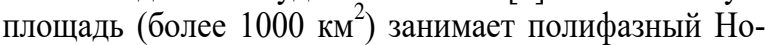
вониколаевский массив, который расположен в северном окончании Алейского антиклинория, имеет субширотно удлиненную форму, с севера ограничен крупным Варшавским разломом. Массив имеет пятифазное строение с гомодромной последовательностью пород от габброидов до лейкогранитов (рис. 1). Изучаемые гранитоиды четвёртой фазы внедрения представлены натриевыми и калиево-натриевыми биотитовыми лейкогранитами, которые образуют крупные штоки, прорывающие породы трёх предшествующих интрузивных фаз.

\section{Методика исследования}

Методика отбора проб гранитоидов и последующая их обработка соответствует общепринятой - дробление пород, «отмучивание», отмывка, разделение в тяжёлых жидкостях, магнитная и электромагнитная сепарация, исследование фракций под бинокулярной лупой, диагностика минералов и отбор зёрен для проведения анализов. Аналитические исследования выпол- нены в Институте геологии и минералогии СО РАН (г. Новосибирск) на электронном сканирующем микроскопе JSM-6510LV (Jeol Ltd) с энергодисперсионным спектрометром INCAEnergy 350+ (анализы выполнены мл. науч. сотр. М.В. Хлестовым при участии автора статьи), на электронном микроскопе TESCAN VEGA 3 SBU, оснащенном приставкой для рентгено-флуоресцентного энерго-дисперсионного анализа (ЭДС) OXFORD X-Max 50 с Si/Li кристаллическим детектором (отделение геологии Инженерной школы природных ресурсов ТПУ, аналитик канд. геол.-минерал. наук М.А. Рудмин), на рентгенофлюоресцентном микроскопе (отделение геологии Инженерной школы природных ресурсов ТПУ, аналитик канд. геол.-минерал. наук М.А. Рудмин). Интерпретация химического состава и определение минералов проводились с применением системы идентификации минералов на основе их стехиометрии (разработана С.В. Канакиным в Геологическом институте СО РАН, г. Улан-Удэ), а также (для редких минералов, не вошедших в базу данных) непосредственным сопоставлением нормативного состава, набора элементовпримесей предполагаемых минералов с полученными данными анализов. Приведённые в работе таблицы химического состава минералов отражают полный набор примесных элементов, без исключения возможного влияния соседних минералов. 


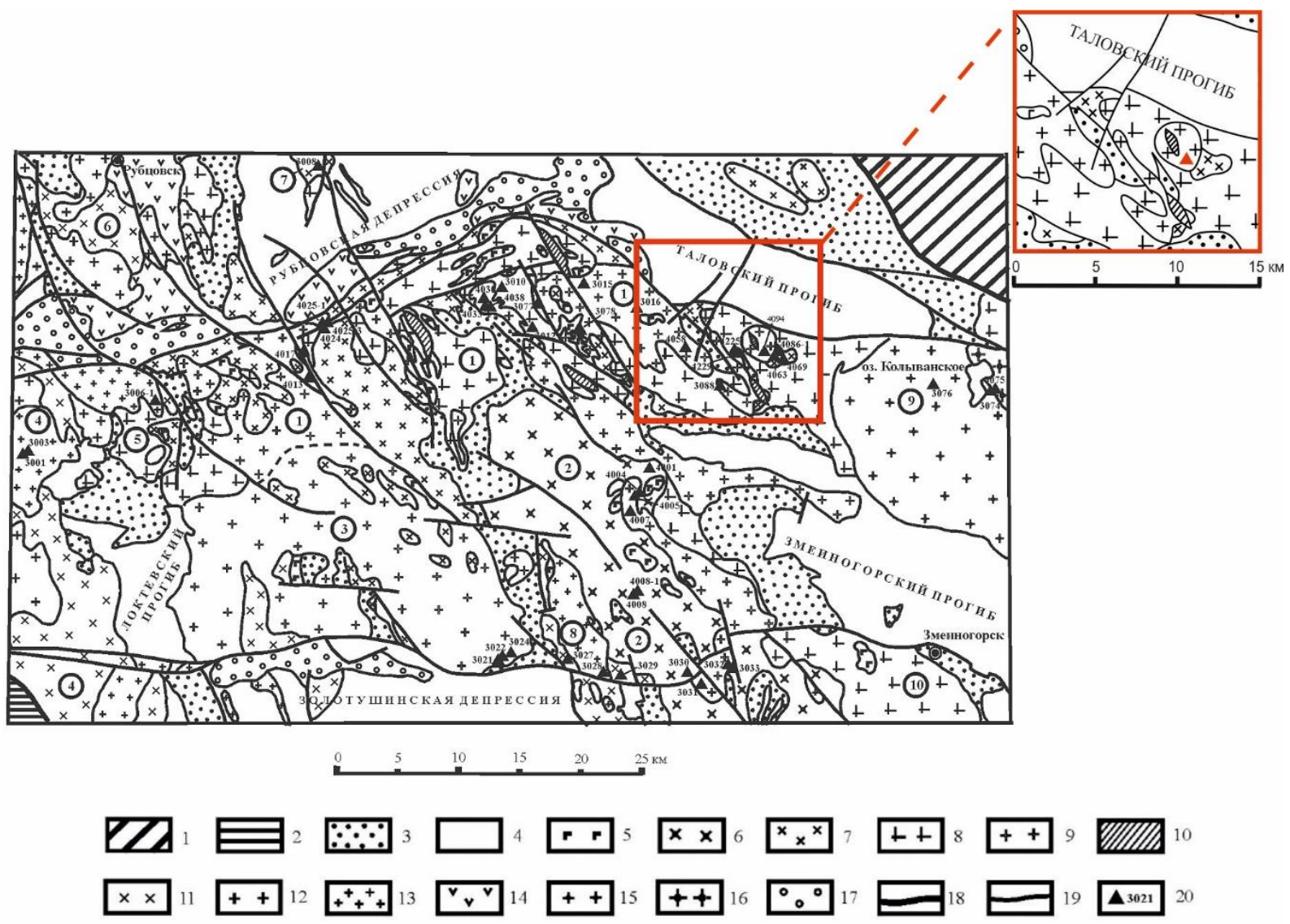

Рис. 1. Схема геологического строения северной части Алейского поднятия Рудного Алтая [1]: 1) каледонские структуры Горного Алтая; 2) гериинские структуры Иртышской зоны смятия; 3, 4) структурновещественные комплексы Рудно-Алтайской зоны (3 - терригенный комплекс основания, 4 - девонский осадочно-вулканогенный комплекс); 5-10) девонский интрузивный комплекс Рудного Алтая (5 - габброиды и диоритоиды ранней фазы, 6 - тоналиты и плагиограниты Алейского массива, 7 - породы второй фазы змеиногорского комплекса, 8 - лейкоплагиограниты третьей фазы змеиногорского комплекса, 9 - лейкогранить четвертой фазы змеиногорского комплекса, в том числе Устьянского массива, 10 - калиевые лейкограниты пятой фазы змеиногорского комплекса); 11-13) интрузивные образования средне-позднекаменноугольного волчихинского (позднезмеиногорского) комплекса (11 - породы ранних фаз, 12 - граниты третьей фазы, 13 - лейкограниты четвертой фазы); 14) вулканогенные образования средне-позднекаменноугольного панфиловского комплекса; 15,16$)$ интрузивные образования пермо-триасового синюшинского комплекса $(15$ - гранитоиды главной фазы, 16 - лейкограниты третьей фазы); 17) приразломные прогибы аккреционноколлизионной и позднеколлизионной стадий; 18) границы структурно-формационных зон; 19) прочие разломы; 20) точки отбора и номера проб. Интрузивные массивы (иифры в кружках): 1) Новониколаевский; 2) Алейский; 3) Устьянский; 4) Локтевский; 5) Новоматвеевский; 6) Рубиовский; 7) Новосклюхинский; 8) Павловский; 9) Саввушкинский; 10) Мохнатые Сопки

Fig. 1. Scheme of the geological structure of the northern part of the Aleisk uplift of the Rudny Altai [1]: 1) Caledonian structures of Gorny Altai; 2) Hercynian structures of the Irtysh crumple zone; 3, 4) structural-material complexes of the Rudny Altai zone (3 - terrigenous complex of the base, 4 - Devonian sedimentary-volcanic complex); 5-10) Devonian intrusive complex of the Ore Altai $(5$ - gabbroids and dioritoids of the early phase, 6 - tonalites and plagiogranites of the Aleisk massif, 7 - rocks of the second phase of the Zmeinogorsk complex, 8 - leukoplagiogranites of the third phase of the Zmeinogorsk complex, 9 - leucogranites of the fourth phase of the Zmeinogorsk complex, including the Ustyansky massif, 10 - potassium leucogranites of the fifth phase of the Zmeinogorsk complex); 11-13) intrusive formations of the Middle-Late Carboniferous Volchikha (Late Zmeinogorsk) complex (11 - rocks of the early phases, 12 - granites of the third phase, 13 - leucogranites of the fourth phase); 14) volcanogenic formations of the Middle-Late Carboniferous Panfilov complex; 15, 16) intrusive formations of the Permian-Triassic Sinyushinsky complex (15 - granitoids of the main phase, 16 - leucogranites of the third phase); 17) near-fault troughs of the accretion-collisional and late collisional stages; 18) boundaries of structural and formation zones; 19) other faults; 20) sampling points and sample numbers. Intrusive massifs (numbers in circles): 1) Novonikolaevsky; 2) Aleisky; 3) Ustyansky; 4) Loktevsky; 5) Novomatveevsky; 6) Rubtsovsky; 7) Novosklyukhinsky; 8) Pavlovsky; 9) Savvushkinsky; 10) Mokhnatye Sopki 


\section{Результаты исследования}

В составе акцессорных минералов лейкогранитов четвёртой интрузивной фазы, наряду с типичными для гранитоидов магнетитом, гематитом, сфеном, цирконом, апатитом и др., установлены в единственном штоке (выноска на рис. 1, точка отбора показана красным цветом) колумбит, ксенотим, торит, монацит и впервые для данного комплекса такие редкие минералы, как фергюсонит, приорит, торианит, ураноторианит. В целом такая минерализация встречается в гранитоидных комплексах различных регионов [2, 3], но в алейско-змеиногорских породах Y-Nb, Y-Ti акцессории, как выше отмечено, присутствуют в единственном теле четвёртой фазы внедрения. Количество их не превышает единичных зёрен.

Фергюсонит $\mathrm{Y}(\mathrm{Nb}, \mathrm{Ta}) \mathrm{O}_{4}$ встречен в срастании с колумбитом. Зерно размером около $90 \times 140 \mu \mathrm{m}$, большая часть сложена фергюсонитом, границы с окружающим колумбитом «заливистые», неправильной формы (рис. 2). Центральная часть зерна разбита продольной трещиной, в которой также развит колумбит. Кроме того, к трещине приурочен хлорит и небольшое зерно ураноторианита. Строение фергюсонита однородное, трещиноватости, за исключением краевых частей, не наблюдается. Стоит отметить, что ассоциация фергюсонита с колумбитом весьма распространена в гранитоидах [4].

Химический состав (табл. 1) соответствует основным характеристикам фергюсонита [5-8]. Так, соотношение Y к общей сумме Y+TR в среднем составляет $65,6 \%$ при нормальных значениях от 63 до $75 \%$. Содержание $\mathrm{CaO}$ не превышает $1 . . .3 \%$. $\mathrm{UO}_{2}$ и $\mathrm{ThO}_{2}$, замещающие $\mathrm{Y}$, не превышают количества 7,55 и $5,91 \%$ соответственно.

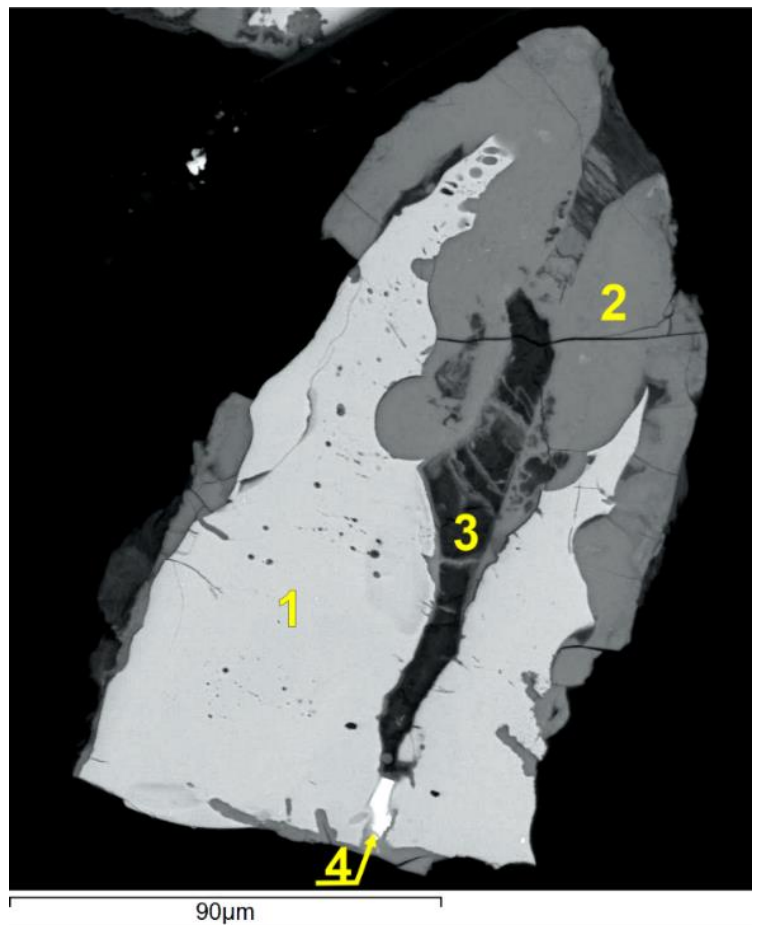

Pис. 2. 1 - фергюсонит в срастании с колумбитом - 2, 3 - хлорит, 4 - ураноторианит. Здесь и на последующих рисунках изображение в обратно рассеянных электронах

Fig. 2. 1 -fergusonite in intergrowth with columbite - 2, 3 - chlorite, 4 - uranotorianite. Here and in the following figures, the image in backscattered electrons

Таблица 1. Химический состав фергюсонита (мас. \%)

Table 1. Fergusonite chemical composition, wt. \%

\begin{tabular}{|c|c|c|c|c|c|c|}
\hline $\begin{array}{c}\text { № ח.I } \\
\text { Ordinal number }\end{array}$ & 1 & 2 & 3 & 4 & 5 & 6 \\
\hline $\mathrm{SiO}_{2}$ & - & 1,35 & - & - & 2,09 & - \\
\hline $\mathrm{CaO}$ & 0,87 & 0,73 & 0,84 & 0,62 & 0,39 & 0,66 \\
\hline $\mathrm{TiO}_{2}$ & 1,7 & 2,17 & 1,51 & 1,55 & 2,59 & 1,07 \\
\hline $\mathrm{Y}_{2} \mathrm{O}_{3}$ & 24,84 & 24,31 & 27,3 & 28,64 & 26,98 & 28,66 \\
\hline $\mathrm{Nb}_{2} \mathrm{O}_{5}$ & 44,18 & 43,76 & 45,6 & 46,57 & 39,48 & 48,61 \\
\hline $\mathrm{Ta}_{2} \mathrm{O}_{5}$ & - & - & 2,06 & - & 3,75 & 1,27 \\
\hline $\mathrm{Ce}_{2} \mathrm{O}_{3}$ & 0,68 & - & - & - & - & - \\
\hline $\mathrm{Na}_{2} \mathrm{O}_{3}$ & 1,43 & 1,36 & 1,19 & 0,88 & 1,11 & - \\
\hline $\mathrm{Sm}_{2} \mathrm{O}_{3}$ & 1,04 & 0,89 & 1,03 & - & - & - \\
\hline $\mathrm{Gd}_{2} \mathrm{O}_{3}$ & 1,84 & 2,44 & 1,62 & 1,7 & 1,72 & - \\
\hline $\mathrm{Dy}_{2} \mathrm{O}_{3}$ & 3,42 & 2,94 & 3,49 & 4,15 & 2,79 & 2,9 \\
\hline $\mathrm{Er}_{2} \mathrm{O}_{3}$ & 2,79 & 2,38 & 2,8 & 3,09 & 3,08 & 3,87 \\
\hline $\mathrm{Yb}_{2} \mathrm{O}_{3}$ & 5,47 & 4,36 & 4,56 & 4,55 & 4,91 & 6,04 \\
\hline $\mathrm{ThO}_{2}$ & 5,91 & 4,85 & 3,56 & 2,1 & 2,39 & 1,5 \\
\hline $\mathrm{UO}_{2}$ & 4,87 & 5,43 & 5,36 & 5,33 & 7,55 & 4,73 \\
\hline $\mathrm{CyMMa/Total}$ & 99,03 & 96,97 & 100,92 & 99,17 & 98,81 & 99,3 \\
\hline $\mathrm{Y} /(\mathrm{Y}+\mathrm{TR}), \%$ & 59,84 & 62,85 & 68,0 & 66,59 & 66,25 & 69,11 \\
\hline
\end{tabular}

Кристаллохимические формуль фергюсонита (номера формул соответствуют порядковым номерам анализов в табл. 1)

1. $\left(Y_{0,614} C a_{0,043} C e_{0,012} N_{0,024} S_{0,017} G d_{0,028} D y_{0,051} E r_{0,041} Y_{0,077}\right)_{0,907}\left(N b_{0,927} T i_{0,059} T h_{0,062} U_{0,05}\right)_{1,098} O_{4}$

2. $\left(Y_{0,613} \mathrm{Ca}_{0,037} \mathrm{Nd} d_{0,023} \mathrm{Sm}_{0,015} \mathrm{G} d_{0,038} D y_{0,045} \mathrm{Er}_{0,035} \mathrm{Yb}_{0,063}\right)_{0,869}\left(\mathrm{Nb}_{0,937} \mathrm{Ti}_{0,077} \mathrm{Th}_{0,052} U_{0,057}\right)_{1,123} \mathrm{O}_{4}$

3. $\left(Y_{0,653} \mathrm{Ca}_{0,04} \mathrm{Nd}_{0,019} \mathrm{Sm}_{0,016} G d_{0,024} \mathrm{Dy_{0,051 }} \mathrm{Er}_{0,04} \mathrm{Yb}_{0,063}\right)_{0,906}\left(\mathrm{Nb}_{0,927} \mathrm{Ti}_{0,051} U_{0,054} \mathrm{Th}_{0,036} \mathrm{Ta}_{0,025}\right)_{1,093} \mathrm{O}_{4}$

4. $\left(Y_{0,687} \mathrm{Ca}_{0,03} \mathrm{Nd}_{0,014} G d_{0,025} \mathrm{Dy} \mathrm{y}_{0,06} \mathrm{Er}_{0,044} \mathrm{Yb}_{0,063}\right)_{0,923}\left(\mathrm{Nb}_{0,95} \mathrm{Ti}_{0,053} U_{0,053} \mathrm{Th}_{0,022}\right)_{1,079} \mathrm{O}_{4}$

5. $\left(Y_{0,651} C a_{0,019} N d_{0,018} G d_{0,026} D y_{0,041} E r_{0,044} Y b_{0,068}\right)_{0,867}\left(N b_{0,81} T i_{0,089} S i_{0,095} T_{0,046} U_{0,076} T h_{0,025}\right)_{1,141} O_{4}$

6. $\left(Y_{0,68} C a_{0,032} D y_{0,042} E r_{0,054} \mathrm{Yb}_{0,082}\right)_{0,89}\left(\mathrm{Nb}_{0,979} \mathrm{Ta}_{0,015} \mathrm{Ti}_{0,036} \mathrm{Th}_{0,015} U_{0,047}\right)_{1,092} \mathrm{O}_{4}$ 
Ещё одно зерно фергюсонита, размером 0,2×0,2 мм, также представляет взаимопрорастания с колумбитом (рис. 3), приуроченным к краевой части зерна и к трещинам, пустотам в фергюсоните. Фергюсонит содержит тонкие вкрапленники (размером в первые микроны) ураноторианита.

Колумбит, образующий срастания с фергюсонитом, характеризуется повышенными содержаниями примесей тория, церия, титана, кальция, фосфора, кремния, алюминия (табл. 2; анализы 1 и 2 отвечают колумбиту на рис. 2, анализы 3-5 - колумбит на рис. 3).

Приорит $\mathrm{Y}(\mathrm{Nb}, \mathrm{Ti})_{2} \mathrm{O}_{6}$ образует слегка удлиненные зерна размером $100 \times 150 \mu \mathrm{m}$ красновато-бурого цвета, со стеклянным блеском. Внутреннее строение зерна однородное, слегка трещиноватое (рис. 4). На границах зерна наблюдаются срастания с кварцем, титанитом, биотитом, апатитом. Химический состав приорита приведен в табл. 3. Обращает внимание отсутствие ниобия, изоморфного с титаном. Пониженные содержания $\mathrm{Nb}$ отмечаются в такой разновидности приорита, как бломстрандин, но полное отсутствие $\mathrm{Nb}$ позволяет предполагать, что описываемый минерал соответствует крайне редким иттрокразиту $(\mathrm{Y}, \mathrm{Th}) \mathrm{Ti}_{2}(\mathrm{O}, \mathrm{OH})_{6}$ или тайиту $\mathrm{HYTi}_{2} \mathrm{O}_{6}[9]$. Кроме того, вероятно присутствие самостоятельного минерально- го вида подобно Ү-ивашироиту $\mathrm{YTaO}_{4}$, не изоструктурному с фергюсонитом [10].

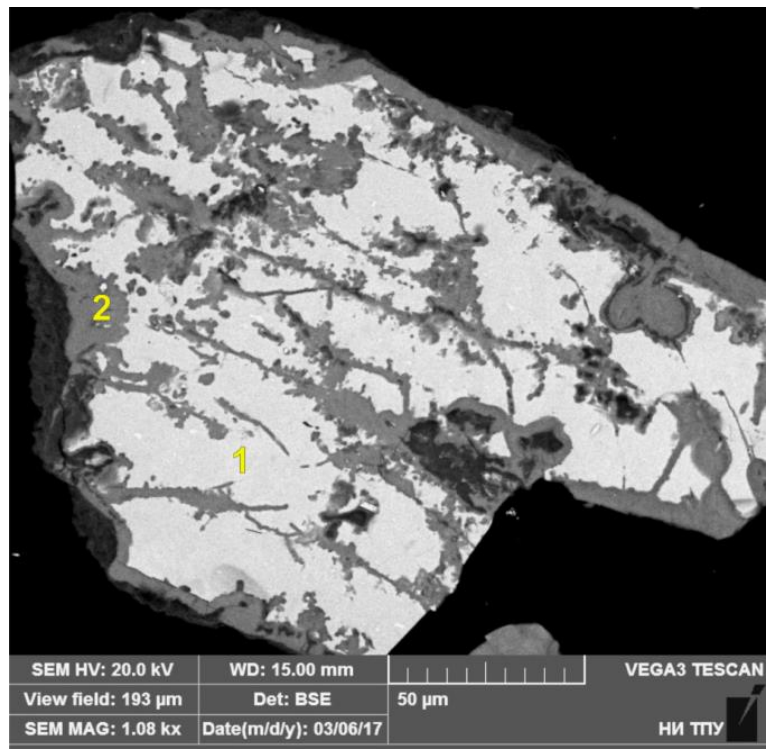

Рис. 3. Фергюсонит (1), колумбит (2), вкрапленники белого ивета - ураноторианит

Fig. 3. Fergusonite (1), columbite (2), inclusions of white color-uranotorianite

Таблица 2. Химический состав колумбита (мас. \%)

Table 2. Columbite chemical composition, wt. \%

\begin{tabular}{|c|c|c|c|c|c|c|c|c|c|c|c|c|}
\hline $\begin{array}{c}\text { № п.П } \\
\text { Ordinal number } \\
\end{array}$ & $\mathrm{Al}_{2} \mathrm{O}_{3}$ & $\mathrm{SiO}_{2}$ & $\mathrm{P}_{2} \mathrm{O}_{5}$ & $\mathrm{CaO}$ & $\mathrm{TiO}_{2}$ & $\mathrm{FeO}$ & $\mathrm{Y}_{2} \mathrm{O}_{3}$ & $\mathrm{Nb}_{2} \mathrm{O}_{5}$ & $\mathrm{Ce}_{2} \mathrm{O}_{3}$ & $\mathrm{Ta}_{2} \mathrm{O}_{5}$ & $\mathrm{ThO}_{2}$ & $\begin{array}{c}\text { Сумма } \\
\text { Total } \\
\end{array}$ \\
\hline 1 & 1,32 & 6,35 & 3,12 & 2,17 & 2,67 & 13,25 & - & 39,53 & - & - & 8,58 & 76,99 \\
\hline 2 & 1,57 & 6,23 & 3,44 & 2,36 & 2,65 & 11,36 & - & 42,8 & 1,62 & 2,26 & 9,31 & 83,59 \\
\hline 3 & 1,15 & 13,62 & 1,22 & 2,35 & 2,17 & 30,78 & $\begin{array}{cc}- & \\
\end{array}$ & 28,62 & 0,63 & 3,7 & 4,94 & 89,18 \\
\hline 4 & 1,64 & 13,56 & 1,16 & 2,81 & 2,51 & 24,88 & - & 30,11 & - & 2,17 & 5,28 & 84,13 \\
\hline 5 & 1,05 & 12,32 & 1,14 & 2,1 & 1,79 & 30,73 & 0,92 & 24,86 & 0,52 & 2,44 & 5,25 & 83,13 \\
\hline
\end{tabular}

Кристаллохимические формулы колумбита (номера формул соответствуют порядковым номерам анализов в табл. 2)

1. $\left(\mathrm{Fe}_{0,759} \mathrm{Ca}_{0,159} \mathrm{Al} \mathrm{l}_{0,106}\right)_{1,024}\left(\mathrm{Nb}_{1,223} \mathrm{Si}_{0,435} \mathrm{P}_{0,181} \mathrm{Ti}_{0,137} \mathrm{Th}_{0,134}\right)_{2,11} \mathrm{O}_{6}$

2. $\left(\mathrm{Fe}_{0,609} \mathrm{Ca}_{0,162} \mathrm{Al} \mathrm{l}_{0,119}\right)_{0,89}\left(\mathrm{Nb}_{1,241} \mathrm{Si}_{0,399} \mathrm{P}_{0,186} \mathrm{Th}_{0,136} \mathrm{Ti}_{0,128} \mathrm{Ta}_{0,039} \mathrm{Ce}_{0,038}\right)_{2,167} \mathrm{O}_{6}$

3. $\left(\mathrm{Fe}_{1,532} \mathrm{Ca}_{0,15} \mathrm{Al} \mathrm{l}_{0,081}\right)_{1,763}\left(\mathrm{Nb}_{0,77} \mathrm{Si}_{0,81} \mathrm{Ti}_{0,097} \mathrm{Th}_{0,067} \mathrm{P}_{0,061} \mathrm{Ce}_{0,014} \mathrm{Ta}_{0,06}\right)_{1,879} \mathrm{O}_{6}$

4. $\left(\mathrm{Fe}_{1,274} \mathrm{Ca}_{0,184} \mathrm{Al} \mathrm{l}_{0,118}\right)_{1,576}\left(\mathrm{Nb}_{0,834} \mathrm{Si}_{0,83} \mathrm{Ti}_{0,116} \mathrm{Th}_{0,074} \mathrm{P}_{0,06} \mathrm{Ta}_{0,036}\right)_{2,05} \mathrm{O}_{6}$

5. $\left(\mathrm{Fe}_{1,663} \mathrm{Ca}_{0,146} \mathrm{Al} \mathrm{l}_{0,08} \mathrm{Y}_{0,032}\right)_{1,921}\left(\mathrm{Nb}_{0,727} \mathrm{Si}_{0,797} \mathrm{P}_{0,062} \mathrm{Ti}_{0,087} \mathrm{Ce}_{0,012} \mathrm{Ta}_{0,043} \mathrm{Th}_{0,077}\right)_{1,808} \mathrm{O}_{6}$

Таблица 3. Химический состав приорита (мас. \%)

Table 3. Priorite chemical composition, wt. \%

\begin{tabular}{|c|c|c|c|c|c|c|c|c|}
\hline $\begin{array}{c}\text { № п.П } \\
\text { Ordinal number }\end{array}$ & $\mathrm{TiO}_{2}$ & $\mathrm{Y}_{2} \mathrm{O}_{3}$ & $\mathrm{Sm}_{2} \mathrm{O}_{3}$ & $\mathrm{Gd}_{2} \mathrm{O}_{3}$ & $\mathrm{Dy}_{2} \mathrm{O}_{3}$ & $\mathrm{Er}_{2} \mathrm{O}_{3}$ & $\mathrm{Yb}_{2} \mathrm{O}_{3}$ & $\begin{array}{c}\text { Cyммa } \\
\text { Total }\end{array}$ \\
\hline 1 & 53,84 & 30,91 & - & 1,69 & 3,74 & 2,7 & 2,9 & 95,79 \\
\hline 2 & 53,33 & 29,86 & 0,51 & 2,51 & 3,79 & 2,92 & 3,36 & 96,27 \\
\hline
\end{tabular}

Кристаллохимические формулы приорита (номера формул соответствуют порядковым номерам анализов в табл. 3) 1. $\left(Y_{0,89} D y_{0,065} Y b_{0,048} E r_{0,046} G d_{0,03}\right)_{1,079} T i_{2,19} O_{6}$

2. $\left(Y_{0,864} D y_{0,066} Y b_{0,056} E r_{0,05} G d_{0,045} S m_{0,01}\right)_{1,091} \mathrm{Ti}_{2,182} \mathrm{O}_{6}$

Ксенотим $\mathrm{YPO}_{4}$ встречается только в виде включений в цирконе, торите. Заслуживает внимания кристалл циркона размером около 0,3 мм с ровными гранными очертаниями и зональным строением (рис. 5). Внешняя зона лишена включений, центральная насыщена многочисленными микровключениями торита, уранинита, присутствие которых обусловлено распадом твёрдого раствора цирконий-торий- уранового состава [11]. Дальнейший рост кристалла в сменившейся физико-химической обстановке привёл к формированию внешней каймы, лишённой включений и примесных элементов. Подобные кристаллы циркона с зональным строением и включениями торита в центральной части описаны в плиоценовых гранитах Карпат [11], в пегматитах Урала [12]. 


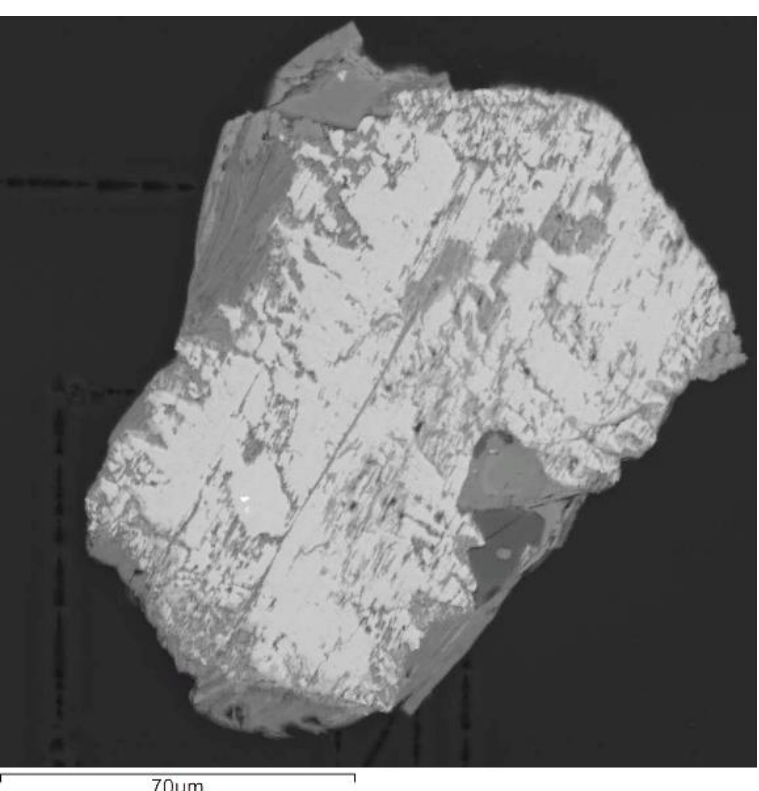

Рис. 4. Зерно приорита

Fig. 4. Priorite grain

Выделения ксенотима, размером $10 \ldots 15 \mu \mathrm{m}$, имеют изометричную, кристаллогранную или неправильную форму, приурочены они к кварцевым вросткам в кристалле циркона (рис. 5). Химический состав представлен в табл. 4 (номера анализов 1-3).

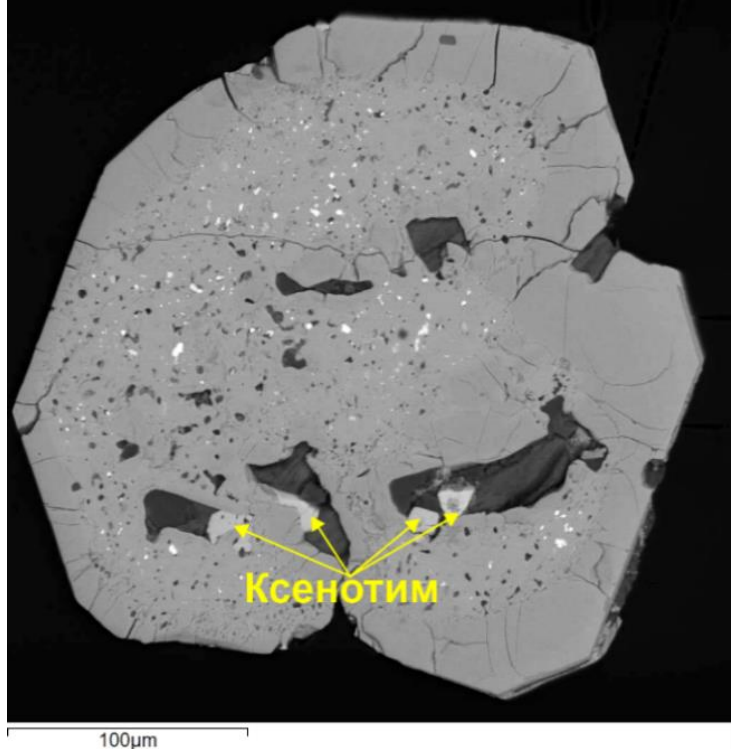

Рис. 5. Кристалл ичиркона. Центральная часть содержит тонкую вкрапленность уранинита (белое), торита (светло-серое)

Fig. 5. Zircon crystal. The central part contains thin inclusions of uraninite (white), thorite (light gray)

Кроме того, ксенотим образует включение в центре зерна торита, размером около $10 \mu \mathrm{m}$ с гранными очертаниями (рис. 6, табл. 4, анализ № 4).

Таблица 4. Химический состав ксенотима (мас. \%)

Table 4. Xenotim chemical composition, wt. \%

\begin{tabular}{|c|c|c|c|c|c|c|c|c|c|c|c|c|}
\hline $\begin{array}{c}\text { № п.П } \\
\text { Ordinal number }\end{array}$ & $\mathrm{SiO}_{2}$ & $\mathrm{P}_{2} \mathrm{O}_{5}$ & $\mathrm{FeO}$ & $\mathrm{Y}_{2} \mathrm{O}_{3}$ & $\mathrm{Gd}_{2} \mathrm{O}_{3}$ & $\mathrm{Dy}_{2} \mathrm{O}_{3}$ & $\mathrm{Er}_{2} \mathrm{O}_{3}$ & $\mathrm{Yb}_{2} \mathrm{O}_{3}$ & $\mathrm{Ta}_{2} \mathrm{O}_{5}$ & $\mathrm{ThO}_{2}$ & $\mathrm{UO}_{2}$ & $\begin{array}{c}\text { Суммa } \\
\text { Total }\end{array}$ \\
\hline 1 & 2,67 & 32,4 & 1,42 & 38,21 & 2,46 & 4,65 & - & 3,48 & - & 1,91 & 1,6 & 88,81 \\
\hline 2 & 3,64 & 31,25 & 1,46 & 36,45 & 2,26 & 3,84 & - & 3,59 & - & 2,92 & 1,82 & 87,23 \\
\hline 3 & 2,42 & 31,64 & - & 35,39 & 3,43 & 5,89 & 4,04 & 5,01 & - & 2,01 & 1,58 & 91,42 \\
\hline 4 & - & 31,9 & 0,96 & 36,55 & 3,02 & 6,06 & 3,37 & 5,27 & 4,18 & 6,61 & - & 97,92 \\
\hline
\end{tabular}

Кристаллохимические формуль ксенотима (номера формул соответствуют порядковым номерам анализов в табл. 4)

1. $\left(Y_{0,725} \mathrm{Fe}_{0,042} \mathrm{Gd}_{0,029} \mathrm{D} \mathrm{y}_{0,053} \mathrm{Yb}_{0,038} \mathrm{Th}_{0,015} U_{0,013}\right)_{0,915}\left(P_{0,978} \mathrm{Si}_{0,095}\right)_{1,073} \mathrm{O}_{4}$

2. $\left(Y_{0,725} \mathrm{Fe}_{0,042} \mathrm{Gd}_{0,029} \mathrm{Dy} \mathrm{y}_{0,053} \mathrm{Yb}_{0,038} \mathrm{Th}_{0,015} U_{0,013}\right)_{0,915}\left(\mathrm{P}_{0,978} \mathrm{Si}_{0,095}\right)_{1,073} \mathrm{O}_{4}$

3. $\left(Y_{0,682} G d_{0,041} D y_{0,069} E r_{0,046} Y_{0,055} T_{0,017} U_{0,013}\right)_{0,923}\left(P_{0,97} S i_{0,088}\right)_{1,058} O_{4}$

4. $\left(Y_{0,696} \mathrm{Fe}_{0,029} \mathrm{Gd}_{0,036} \mathrm{Dy} \mathrm{y}_{0,07} \mathrm{Er}_{0,038} \mathrm{Yb}_{0,058} \mathrm{Ta}_{0,041} \mathrm{Th}_{0,054}\right)_{1,022} \mathrm{P}_{0,966} \mathrm{O}_{4}$

Таблица 5. Химический состав торита (мас. \%)

Table 5. Thorit chemical composition, wt. \%

\begin{tabular}{|c|c|c|c|c|c|c|c|c|c|c|c|}
\hline $\begin{array}{c}\text { № ח.П } \\
\text { Ordinal number }\end{array}$ & $\mathrm{F}$ & $\mathrm{Al}_{2} \mathrm{O}_{3}$ & $\mathrm{SiO}_{2}$ & $\mathrm{P}_{2} \mathrm{O}_{5}$ & $\mathrm{CaO}$ & $\mathrm{FeO}$ & $\mathrm{Y}_{2} \mathrm{O}_{3}$ & $\mathrm{PbO}$ & $\mathrm{ThO}_{2}$ & $\mathrm{UO}_{2}$ & $\begin{array}{c}\text { Cyмma } \\
\text { Total }\end{array}$ \\
\hline 1 & 0,79 & 0,38 & 15,32 & 0,71 & - & - & 2,83 & - & 62,02 & 6,58 & 88,62 \\
\hline 2 & 1,63 & 0,47 & 16,84 & - & 1,08 & 1,52 & - & - & 63,31 & 7,49 & 92,34 \\
\hline 3 & 1,15 & 0,72 & 18,06 & - & 0,71 & 1,63 & - & - & 66,59 & 3,53 & 92,39 \\
\hline 4 & - & - & 18,31 & - & - & - & - & 1,22 & 71,55 & 6,61 & 97,7 \\
\hline 5 & - & - & 18,87 & - & - & - & - & 1,41 & 72,06 & 5,55 & 97,89 \\
\hline
\end{tabular}

Кристаллохимические формулы торита (номера формул соответствуют порядковым номерам анализов в табл. 5)

1. $\left(\mathrm{Th}_{0,852} U_{0,088} Y_{0,091}\right)_{1,031}\left[\left(\mathrm{Si}_{0,925} \mathrm{Al}_{0,027} P_{0,001}\right)_{0,953} \mathrm{O}_{4}\right]$

2. $\left(\mathrm{Th}_{0,804} \mathrm{Ca}_{0,06} \mathrm{Fe}_{0,065} U_{0,093}\right)_{1,022}\left[\left(\mathrm{Si}_{0,94} \mathrm{Al} \mathrm{l}_{0,031}\right)_{0,971} \mathrm{O}_{4}\right.$

3. $\left(\mathrm{Th}_{0,828} \mathrm{Ca}_{0,042} \mathrm{Fe}_{0,074} U_{0,043}\right)_{0,987}\left[\left(\mathrm{Si}_{0,987} \mathrm{Al}_{0,046}\right)_{1,033} \mathrm{O}_{4}\right.$

4. $\left(T h_{0,899} P b_{0,018} U_{0,081}\right)_{0,998}\left[S i_{1,011} O_{4}\right]$

5. $\left(\mathrm{Th}_{0,894} \mathrm{~Pb} b_{0,021} U_{0,067}\right)_{0,982}\left[\mathrm{Si}_{1,029} \mathrm{O}_{4}\right]$

Topum $\mathrm{Th}\left[\mathrm{SiO}_{4}\right]$ встречается в виде отмеченных выше микронных вкрапленников в цирконе, в монаците, а также образует отдельные зерна. Зерно торита размером $\sim 100 \times 150 \mu \mathrm{m}$ имеет неоднородное строение (рис. 6), центральная часть представлена собственно торитом (табл. 5, анализ № 1) и содержит отмеченное 
ранее включение ксенотима. Периферия зерна сложена торианитом (на снимке в обратно рассеянных электронах - серого цвета, темнее центральной части зерна), границы зон торита и торианита неровные, размытые, часто напоминают графические прорастания. Такое же взаимоотношение торита и торианита встречено в другом зерне, имеющем близкие кристаллогранным очертания (размером $\sim 0,2$ мм) (рис. 7). Торит, слагающий бо́льшую центральную часть зерна, состоит из двух зон, внутренняя (округлой формы, на снимке выглядит темнее) обогащена примесями железа, кальция, алюминия, фтора (табл. 5, анализы № 2, 3). Окружающая эту зону, преобладающая по размеру область сложена торитом, практически не имеющим примесей (присутствуют лишь свинец и уран (табл. 5, анализы № 4, 5). Торит окружён достаточно ровной, выдержанного размера каймой торианита.

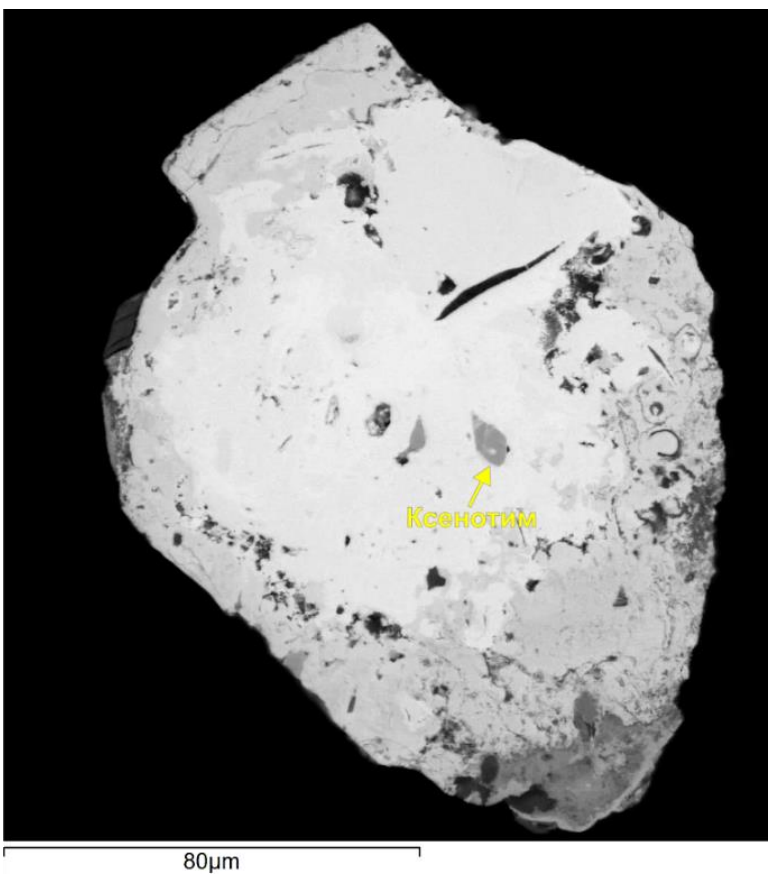

Рис. 6. Зерно торита, периферическая зона сложена торианитом

Fig. 6. Thorite grain, the peripheral zone is composed of thorianite

Существенно отличается по внутреннему строению зерно торита с ярко выраженной зональностью (рис. 8). Границы зон неровные, волнистые, напоминают колломорфные выделения, имеют дентритовидные очертания. Местами разрывы между зонами заполнены хлоритом (на рис. 8 имеют чёрную окраску). Различия между зонами выражаются в составе и количестве примесных элементов. Центральная часть (I на рис. 8) характеризуется только примесями $\mathrm{UO}_{2}$ до $8 . .9$ мас. \% и $\mathrm{PbO}(1,4 \ldots 1,6$ мас. \%). В следующей зоне (II) торит содержит существенно меньше $\mathrm{UO}_{2}$ $\left(3,3 \ldots 4,5\right.$ мас. \%), появляются примеси $\mathrm{Al}_{2} \mathrm{O}_{3}$ (0,5 мас. \%) и $\mathrm{F}(3,5 \%)$. Третья зона (III) характеризуется отсутствием $\mathrm{UO}_{2}$, таким же содержанием $\mathrm{Al}_{2} \mathrm{O}_{3}$, несколько пониженным $\mathrm{F}(1,88 \ldots 2,33 \%)$, но появляются примеси $\mathrm{CaO}, \mathrm{TiO}_{2}, \mathrm{FeO}, \mathrm{ZrO}_{2}, \mathrm{Nb}_{2} \mathrm{O}_{5}$. Внешняя 30- на (IV) содержит ещё меньше $\mathrm{F}$, а количество $\mathrm{CaO}$, $\mathrm{TiO}_{2}, \mathrm{FeO}, \mathrm{ZrO}_{2}, \mathrm{Nb}_{2} \mathrm{O}_{5}$ возрастает.

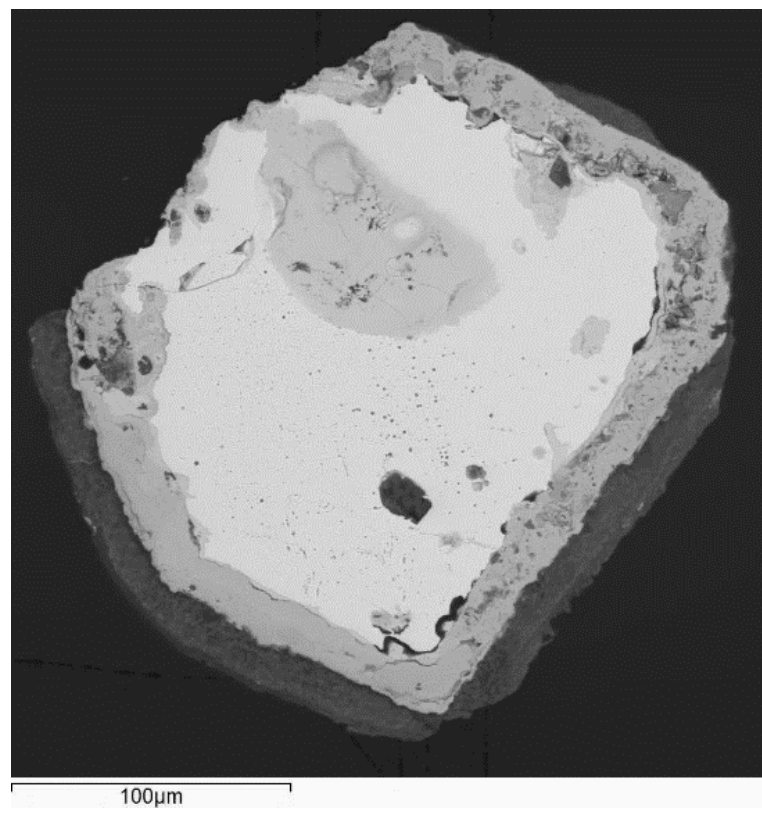

Рис. 7. Зерно торита с частично кристаллогранной формой, периферическая зона (тёмно-серая) сложена торианитом

Fig. 7. Thorite grain with a partially crystal-faceted shape, the peripheral zone (dark gray) is composed of thorianite

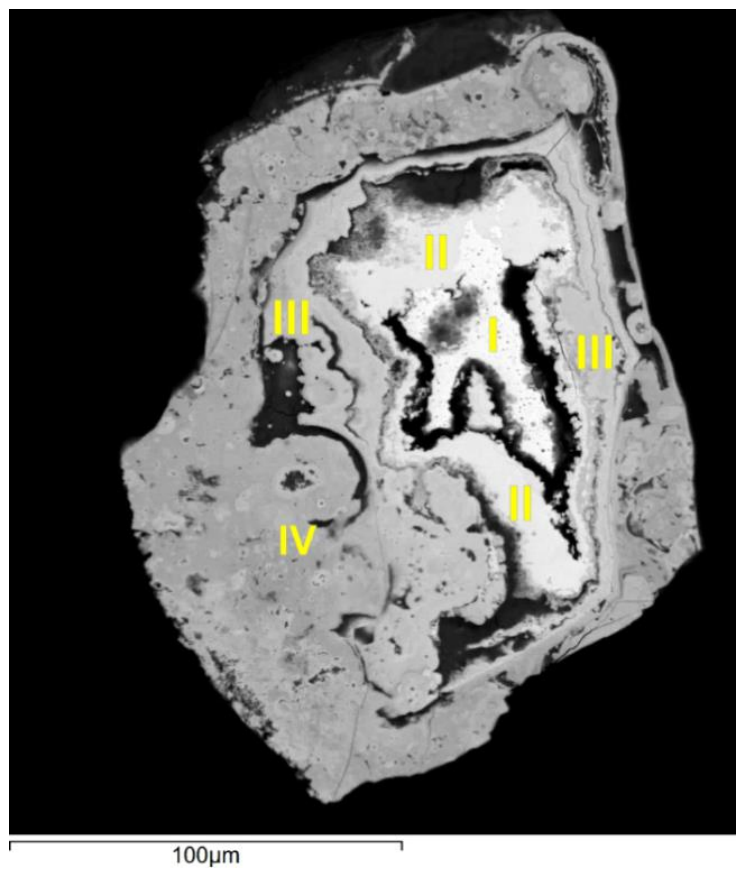

Pис. 8. Зерно торита

Fig. 8. Thorit grain

Торианит $\mathrm{ThO}_{2}$, образующий внешние зоны вокруг зёрен торита (рис. 6, 7), характеризуется примесями РЗЭ, фтора, фосфора, алюминия, кальция, железа, стронция, то есть главным образом теми же, что торит центральной части зёрен, кроме фосфора, редких земель и стронция (табл. 6). 
Таблица 6. Химический состав торианита (мас. \%)

Table 6. Thorianit chemical composition, wt. \%

\begin{tabular}{|c|c|c|c|c|c|c|c|c|c|c|c|c|c|}
\hline $\begin{array}{c}\text { № П.П } \\
\text { Ordinal number }\end{array}$ & $\mathrm{F}$ & $\mathrm{Al}_{2} \mathrm{O}_{3}$ & $\mathrm{SiO}_{2}$ & $\mathrm{P}_{2} \mathrm{O}_{5}$ & $\mathrm{CaO}$ & $\mathrm{FeO}$ & $\mathrm{SrO}$ & $\mathrm{La}_{2} \mathrm{O}_{3}$ & $\mathrm{Ce}_{2} \mathrm{O}_{3}$ & $\mathrm{Pr}_{2} \mathrm{O}_{3}$ & $\mathrm{Nd}_{2} \mathrm{O}_{3}$ & $\mathrm{ThO}_{2}$ & $\begin{array}{c}\text { Сyмma } \\
\text { Total }\end{array}$ \\
\hline 1 & 4,37 & - & 0,83 & 6 & 6 & 1,18 & 0,75 & 3,54 & - & - & 3,34 & 51,14 & 77,15 \\
\hline 2 & 3,88 & 0,57 & 1,48 & 7,17 & 6,23 & 2,03 & 0,59 & 4,46 & 3,55 & - & 3,03 & 46,49 & 79,48 \\
\hline 3 & 6,41 & - & 1,39 & 1,08 & 8,75 & 0,87 & - & - & - & - & - & 59,08 & 77,58 \\
\hline 4 & 5,73 & - & 1,39 & 0,87 & 8,72 & 0,86 & 0,48 & 1,4 & 1,63 & 0,59 & - & 57,83 & 79,49 \\
\hline 5 & 6,56 & - & 1,8 & 1,15 & 8,59 & 2,21 & - & 3,79 & 4,47 & - & - & 49,83 & 78,4 \\
\hline
\end{tabular}

Кристаллохимические формуль торианита (номера формул соответствуют порядковым номерам анализов в табл. 6)

1. $\left(\mathrm{Th}_{0,563} \mathrm{Ca}_{0,311} \mathrm{Fe}_{0,048} \mathrm{La}_{0,063} \mathrm{Nd}_{0,058}\right)_{1,043} \mathrm{O}_{2}$

2. $\left(\mathrm{Th}_{0,507} \mathrm{Ca}_{0,32} \mathrm{Fe}_{0,081} \mathrm{La}_{0,079} \mathrm{Ce}_{0,062} \mathrm{Nd}_{0,052}\right)_{1,101} \mathrm{O}_{2}$

3. $\left(\mathrm{Th}_{0,571} \mathrm{Ca}_{0,398} \mathrm{Fe}_{0,031}\right)_{1} \mathrm{O}_{2}$

4. $\left(\mathrm{Th}_{0,555} \mathrm{Ca}_{0,394} \mathrm{Fe}_{0,03} \mathrm{La}_{0,022} \mathrm{Ce}_{0,025} \mathrm{Pr}_{0,009}\right)_{1,035} \mathrm{O}_{2}$

5. $\left(\mathrm{Th}_{0,466} \mathrm{Ca}_{0,378} \mathrm{Fe}_{0,076} \mathrm{La}_{0,057} \mathrm{Ce}_{0,067}\right)_{1,044} \mathrm{O}_{2}$

Таблица 7. Химический состав монацита (мас. \%)

Table 7. Monazit chemical composition, wt. \%

\begin{tabular}{|c|c|c|c|c|c|c|c|c|c|c|c|}
\hline $\begin{array}{c}\text { № п.п } \\
\text { Ordinal number }\end{array}$ & $\mathrm{SiO}_{2}$ & $\mathrm{P}_{2} \mathrm{O}_{5}$ & $\mathrm{CaO}$ & $\mathrm{La}_{2} \mathrm{O}_{3}$ & $\mathrm{Ce}_{2} \mathrm{O}_{3}$ & $\mathrm{Pr}_{2} \mathrm{O}_{3}$ & $\mathrm{Nd}_{2} \mathrm{O}_{3}$ & $\mathrm{Sm}_{2} \mathrm{O}_{3}$ & $\mathrm{Gd}_{2} \mathrm{O}_{3}$ & $\mathrm{ThO}_{2}$ & $\begin{array}{c}\text { Cyмma } \\
\text { Total }\end{array}$ \\
\hline 1 & 3,44 & 24,43 & 0,46 & 14,27 & 27,71 & 3,03 & 8,62 & 1,3 & 0,92 & 14,5 & 98,69 \\
\hline 2 & 0,98 & 28,18 & 0,46 & 16,92 & 31,74 & 3,24 & 9,46 & 1,22 & 0,97 & 5,29 & 98,47 \\
\hline 3 & 2,44 & 26,12 & 0,49 & 14,65 & 28,86 & 2,61 & 9,66 & - & - & 11,93 & 96,75 \\
\hline
\end{tabular}

Кристаллохимические формуль монацита (номера формул соответствуют порядковым номерам анализов в табл. 7)

1. $\left(\mathrm{Ce}_{0,422} \mathrm{La}_{0,219} \mathrm{Th}_{0,137} \mathrm{Pr}_{0,046} \mathrm{Nd}_{0,128} \mathrm{Sm}_{0,019} \mathrm{Gd}_{0,013} \mathrm{Ca}_{0,02}\right)_{1,004}\left[\left(\mathrm{P}_{0,86} \mathrm{Si}_{0,143}\right)_{1,003} \mathrm{O}_{4}\right]$

2. $\left(\mathrm{Ce}_{0,465} \mathrm{La}_{0,251} \mathrm{Th}_{0,049} \mathrm{Pr}_{0,048} \mathrm{Nd}_{0,136} \mathrm{Sm}_{0,017} \mathrm{Gd}_{0,013} \mathrm{Ca}_{0,02}\right)_{0,999}\left[\left(\mathrm{P}_{0,962} \mathrm{Si}_{0,039}\right)_{1,001} \mathrm{O}_{4}\right]$

3. $\left(\mathrm{Ce}_{0,437} \mathrm{La}_{0,224} \mathrm{Pr}_{0,039} \mathrm{Nd}_{0,142} \mathrm{Th}_{0,112} \mathrm{Ca}_{0,022}\right)_{0,976}\left[\left(\mathrm{P}_{0,915} \mathrm{Si}_{0,1}\right)_{1,015} \mathrm{O}_{4}\right]$

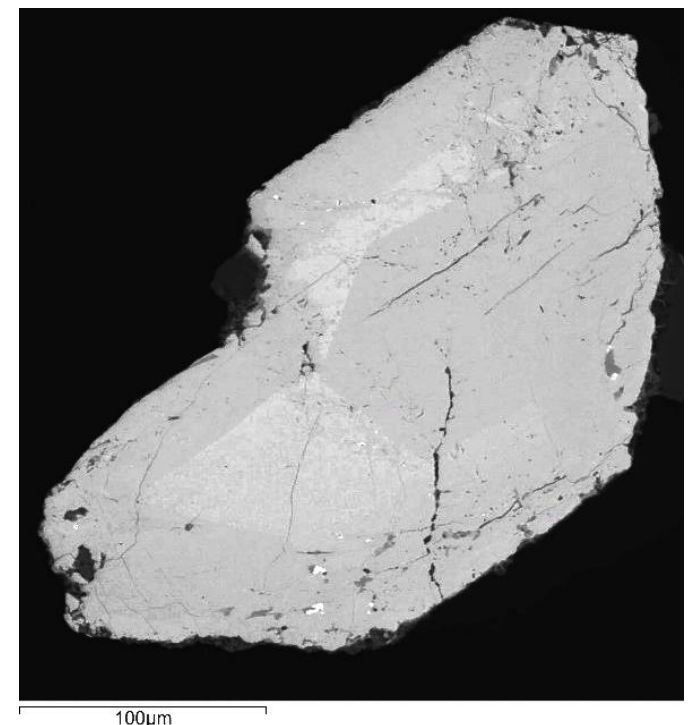

Рис. 9. Фрагмент кристалла монаџита с блоковозональным внутренним строением

Fig. 9. Fragment of a monazite crystal with a block-zonal internal structure

Кристалл монациита $(\mathrm{Ce}, \mathrm{La})\left[\mathrm{PO}_{4}\right]$, размером 0,2×0,3 мм, с не полностью сохранившимися гранями, обладает блоково-зональным строением (рис. 9). В сечении наблюдается три зоны, центральная имеет прямолинейные очертания, повторяющие облик кристалла, сменяется чуть более светлой зоной, также с прямолинейными границами, и внешняя зона несколько темнее предыдущей. Наблюдаемые зоны отличаются по количеству примесных элементов, наиболее изменчивы содержания $\mathrm{ThO}_{2}$ и $\mathrm{SiO}_{2}$ (табл. 7).

\section{Обсуждение результатов исследования и выводы}

Гранитоиды алейско-змеиногорского комплекса $\left(\mathrm{D}_{2-3}\right)$ несут разнообразную акцессорную минерализацию, наиболее обогащены редкими, редкоземельными, радиоактивными акцессориями лейкограниты четвёртой интрузивной фазы $[1,13]$, что вполне естественно, поскольку редкоземельно-иттриевую минерализацию нередко генетически связывают с гранитлейкогранитовыми комплексами [14].

Генезис фергюсонита, приорита, торианита, ксенотима, монацита рассматривается [5, 7, 15-17] главным образом как пегматитовый, торит - магматогенный акцессорный минерал гранитоидов. Фергюсонит нередко встречается в составе пегматитов западной части Алтае-Саянской складчатой области $[18,19]$. В отдельных случаях формирование иттриевых и редкоземельных минералов на постмагматической стадии кристаллизации связывается с фракционированием из расплава лёгких лантаноидов и Y [20]. Особенность алейско-змеиногорских гранитоидов заключается в отсутствии их пегматитов, собственно пегматитовый этап, как следующий за магматическим, не получил здесь развития. Как уже отмечалось [13], акцессорные минералы, присущие гранитным пегматитам, встречаются в апикальных и краевых частях гранитоидных тел. Вероятно, связано это с тем, что на завершающей стадии формирования гранитных интрузивов накапливался остаточный раствор, обогащённый $\mathrm{Nb}, \mathrm{Ti}, \mathrm{Y}, \mathrm{TR}$ и другими элементами, обусловливающими минерализацию последующих пегматитовых образований, но, не имея возможности реализоваться в пегматитовом процессе, такие растворы в апикальных и апикально-краевых частях интрузи- 
вов обусловили интенсивный автометасоматоз, в результате которого типичные пегматитовые минералы (ильменорутил, скандистый ферроколумбит [9], уранториевый редкоземельный ксенотим [13]) сформировались в гранитоидных телах. Появление в гранитах акцессорных фергюсонита, приорита, торианита, ксенотима, монацита обусловлено такой же автометасоматической переработкой апикальных и краевых частей интрузива растворами, насыщенными пегматофильными элементами.

Описываемые акцессории обнаружены только в одной пробе лейкогранитов Новониколаевского массива и именно на участке, где проявилось своеобразное взаимоотношение гранитоидных тел нескольких фаз внедрения (рис. 1). Основной объём пород здесь представлен лейкоплагиогранитами III интрузивной фазы, в их центральной части расположен округлый шток изучаемых лейкогранитов IV фазы, внутри которого находится линзовидное тело калиевых лейкогранитов завершающей фазы становления комплекса. Такое взаиморасположение указывает на существование здесь подводящего канала внедрения расплавов

\section{СПИСОК ЛИТЕРАТУРЫ}

1. Туркин Ю.А., Новоселов К.Л. Петролого-геохимические особенности девонских гранитоидов северо-западной части Рудного Алтая // Известия Томского политехнического университета Инжиниринг георесурсов. - 2012. - Т. 321. - № 1. - С. 5-15.

2. A preliminary study of rare-metal mineralization in the Himalayan leucogranite belts, South Tibet / Wang RuCheng, Wu FuYuan, Xie Lei, Liu XiaoChi, Wang JiaMin, Yang Lei, Lai Wen, Liu Chen // Science China. Earth Sciences. - 2017. - V. 60. - № 9. - P. 1655-1663.

3. Petrological and geochemical characteristics of REE mineralization in the A-type French Creek Granite, New Zealand / R. Morgenstern, R.E. Turnbull, P.A. Ashwell, T.W. Horton, Ch. Oze // Mineralium Deposita. - 2019. - V. 54. - P. 935-958.

4. Фергусонит-(Ү) и продукты его изменения в гранитном пегматите жилы Береговой Зенковского массива на Урале / В.И. Попова, Е.И. Чурин, И.А. Блинов, В.А. Губин // Новые данные о минералах. - 2012. - № 47. - С. 47-55.

5. Минералы (справочник). Т. ІІ. Вып. 3. Сложные окислы, титанаты, ниобаты, танталаты, антимонаты, гидроокислы / под ред. Ф.В. Чухрова, Э.М. Бонштедт-Куплетской. - М.: Наука, 1967. - C. 251-260

6. Hydrothermal genesis of $\mathrm{Nb}$ mineralization in the giant Bayan Obo REE-Nb-Fe deposit (China): Implicated by petrography and geochemistry of Nbbearing minerals / Shang Liua, Lin Dinga, HongRui Fanc, Kui-Feng Yangc, Yan-Wen Tangf, Hai-Dong Shec, Meizhen Hao // Precambrian Research - 2020 - V. 348 - P. 1-24.

7. Enrichment of REE and HFSE during the magmatic-hydrotherma evolution of the Baerzhe alkaline granite, NE China: Implications for rare metal mineralization / Wu-Bin Yang, He-Cai Niua, NingBo Li, Pete Hollings, Shannon Zurevinski, Chang-Ming Xinga // Lithos. - 2020. - V. 358-359. - P. 1-20.

8. Макагонов Е.П., Муфтахов В.А. Редкоземельно-редкометалльная минерализация в поздних гранитах сыростанского массива (Южный Урал) // Литосфера. - 2015. - № 2. - С. 121-132.

9. Солодов Н.А., Семенов Е.И., Бурков В.В. Геологический справочник по тяжелым литофильным редким металлам / под ред. Н.П. Лаверова. - М.: Недра, 1987. - 438 с.

10. Iwashiroite-(Y), $\mathrm{YTaO} 4$, a new mineral from Suishoyama, Kawamata Town, Fukushima Prefecture, Japan / H. Hori, T. Kobayashi， R. Miyawaki， S. Matsubara, K. Yokoyama, нескольких последовательных фаз. Более того, данный канал продолжал действовать в среднепозднекаменноугольное время, когда здесь же внедрились небольшие тела ранних фаз волчихинского комплекса. Именно с приуроченностью к долгоживущему интрузивному каналу связано появление только в этих лейкогранитовых телах редких акцессорных минералов, обогащённых редкоземельными, радиоактивными элементами. Распределение редких элементов в породах IV фазы алейскозмеиногорского комплекса показывает в изучаемых лейкогранитах, приуроченных к данному подводящему каналу, превышение содержаний большинства элементов-примесей (кроме $\mathrm{V}, \mathrm{Sr}, \mathrm{Cs}, \mathrm{Ba}$ и лёгких лантаноидов) над средними значениями во всех лейкогранитах данной фазы. Канал поступления гранитоидных расплавов из первичного очага был максимально благоприятен для поступления ниобия, титана, редкоземельных, радиоактивных элементов, которые в дальнейшем сформировали уникальную ассоциацию акцессорных минералов в данном теле новониколаевских лейкогранитов четвертой фазы.

M. Shimizu // Journal of Mineralogical and Penological Sciences. 2006. - V. 101. - P. 170-177.

11. Huraiová M., Konečný P., Hurai V. Niobium mineralogy of Pliocene A1-type granite of the Carpathian Back-Arc Basin, Central Europe // Minerals. - 2019. - V. 9. - № 488. - P. 1- 16.

12. Новые находки редких минералов в пегматитах Вишнёвых гор на Южном Урале / В.И. Попова, В.А. Попов, И.А. Блинов, В.А. Котляров, А.В. Касаткин, Р. Шкода, С.М Лебедева // Минералогия. -2019 . - Т. 5. - № 1. - С. 3-14.

13. Новоселов К.Л. Акцессорные ниобий-танталовые минералы Алейского гранитного массива (С3 Рудного Алтая) // Известия Томского политехнического университета. Инжиниринг георесурсов. -2020 . - Т. 331. - № 2. - С. 38-44.

14. Рафиков Я.М., Юсупов Р.Г Продуктивность и рудоносность пород гранит-лейкогранитового комплекса на редкие земли, иттрий (чаткало-кураминская континентальная окраина) // Отечественная геология. - 2013. - № 1. - С. 59-69.

15. Бетехтин А.Г. Минералогия. - М.: Госгеолиздат, 1950 - 956 c.

16. Highly fractionated Himalayan leucogranites and associated raremetal mineralization / Fu-Yuan Wu, Xiao-Chi Liu, Zhi-Chao Liu, Ru-ChengWang, Lei Xie, Jia-MinWanga, Wei-Qiang Ji, Lei Yang, Chen Liuc, Gautam Prashad Khanal, Shao-Xiong He // Lithos. 2020. - V. 352 - 353. - P. 1-24.

17. Magmatic evolution and W-Sn-U-Nb-Ta mineralization of the Mesozoic Jiulongnao granitic complex, Nanling Range, South China / Na-Xin Guoa, Zheng Zhaoa, Jian-Feng Gaob, Wei Chenc, Deng-Hong Wanga, Yu-Chuan Chena // Ore Geology Reviews. 2018 - V. 94 - P. 414-434.

18. Гусев А.И. Типизация пегматитовой минерализации Алтая // Современные наукоемкие технологии. - 2014. - № 3. - С. 93-97.

19. Гусев А.И. Редкометалльные пегматиты западной части Алтае-Саянской складчатой области // Известия АО РГО. 2015. - № 3 (38). - C. 16-24.

20. Редкоземельные минералы в породах Катугинского редкометалльного месторождения (восточное Забайкалье): поведение лантаноидов и Ү при кристаллизации насыщенного фтором агпаитового расплава / В.Б. Савельева, Е.П. Базарова, Е.А. Хромова, С.В Канакин // Записки Российского минералогического общества. - 2017. - Т. 146. - № 4. - С. 1-21.

Поступила 09.06.2021 г.

Новоселов К.Л., кандидат геолого-минералогических наук, доцент отделения геологии Инженерной школы природных ресурсов, Национальный исследовательский Томский политехнический университет. 
UDC 549:553.493.66(571.151)

\title{
YTTRIUM RARE-EARTH AND RARE-METAL ACCESSORY MINERALS OF LEUCOGRANITES IN THE ALEYSK ZMEINOGORSK COMPLEX (RUDNY ALTAY)
}

\author{
Konstantin L. Novoselov, \\ novoselov@tpu.ru \\ National Research Tomsk Polytechnic University, \\ 30, Lenin avenue, Tomsk, Russia, 634050.
}

The relevance and aim. The study of granitoids confined to the Aleysk Zmeinogorsk complex for the first time revealed the presence of rare accessory minerals of yttrium (priorite, fergusonite) in a sample spot of leucogranites of phase IV. According to the available data, these minerals are of pegmatitic, pneumatolith-hydrothermal and metasomatic origin, however their development at the magmatic stage is considered less common. The aim of the study is to reveal the origin of priorite and fergusonite in the Aleysk Zmeinogorsk leucogranites, as well as to explain the presence of yttrium and accessory rare-earth elements within the only intrusive zone.

Research methods involve conventional mineralogical and petrographical methods, identification of accessory minerals and analysis of their composition using crashed samples; analytical studies were performed on an electronic scanning microscope JSM-6510LV (Jeol Ltd) fitted with an energy dispersive spectrometer INCA Energy 350+ in a laboratory of the Geology and Mineralogy Institute of the Siberian branch of the Russian Academy of Science (Novosibirsk) and X-ray fluorescence microscope (the Division for Geology, School of Earth Science and Engineering, TPU).

Results. In line with earlier discovered yttrium (xenotime), rare-earth monazite, niobates (columbite, ilmenorutile), rare accessory minerals of ytrium-niobium and yttrium-titanium composition were identified in granitoids of the Aleysk Zmeinogorsk complex.

Conclusions. The presence of priorite and fergusonite in a stock of leucogranites of IV intrusive phase allows the assumption that it was formed due to continuous inflow of melting rocks during successive intrusive phases. The inflow of intrusive material from the initial magma chamber served as a favorable condition for the rocks to be saturated with yttrium, rare-earth elements, and rare metals. The accessory minerals of corresponding composition occurred at the final stage of intrusion formation as a result of autometasomatism of its apical parts and selvages.

\section{Key words:}

Rudny Altay, granitoids, accessory minerals, priorite, fergusonite, xenotime, thorite, thorianite, monazite.

\section{REFERENCES}

1. Turkin Yu.A., Novoselov K.L. Petrological and geochemical features of Devonian granitoids in north-west part of Rudny Altai Bulletin of the Tomsk Polytechnic University, 2012, vol. 321, no. 1, pp. 5-15. In Rus.

2. Wang RuCheng, Wu FuYuan, Xie Lei, Liu XiaoChi, Wang JiaMin, Yang Lei, Lai Wen \& Liu Chen. A preliminary study of rare-metal mineralization in the Himalayan leucogranite belts, South Tibet. Science China. Earth Sciences, 2017, vol. 60, no. 9, pp. $1655-1663$.

3. Morgenstern R., Turnbull R.E., Ashwell P.A., Horton T.W., Oze Ch Petrological and geochemical characteristics of REE mineralization in the A-type French Creek Granite, New Zealand. Mineralium Deposita, 2019, vol. 54, pp. 935-958.

4. Popova V.I., Churin E.I., Blinov I.A., Gubin V.A. Fergusonite-(Y) and its alteration products in granitic pegmatite of Beregovaya vein from Zenkovsky massive in the Urals. New mineral data 2012, no. 47, pp. 47-55. In Rus.

5. Mineraly. Spravochnik [Minerals. Reference book]. Slozhnye okisly, titanaty, niobaty, tantalaty, antimonaty, gidrookisly [Complex oxides, titanates, niobates, tantalates, antimonates, hydrous oxides]. Eds. F.V. Chukhrov, E.M. Bonshtedt-Kupletskaya. Moscow, Nauka Publ., 1967. Vol. II, Iss. 3, pp. 251-260.

6. Shang Liua, Lin Dinga, Hong-Rui Fanc, Kui-Feng Yangc, YanWen Tangf, Hai-Dong Shec, Mei-zhen Hao. Hydrothermal genesis of $\mathrm{Nb}$ mineralization in the giant Bayan Obo REE-Nb-Fe deposit (China): Implicated by petrography and geochemistry of Nbbearing minerals. Precambrian Research, 2020, vol. 348, pp. 1-24.

7. Wu-Bin Yang, He-Cai Niua, Ning-Bo Li, Pete Hollings, Shannon Zurevinski, Chang-Ming Xinga. Enrichment of REE and HFSE during the magmatic-hydrothermal evolution of the Baerzhe alkaline granite, NE China: Implications for rare metal mineralization Lithos, 2020, vol. 358-359. pp. 1-20.

8. Makagonov E.P., Muftakhov V.A. Rare-earth and rare-metal mineralization in late granite of syrostan massif (Southern Urals). Lithosphere, 2015, no. 2, pp. 121-132. In Rus.
9. Solodov N.A., Semenov E.I., Burkov V.V. Geologicheskiy spravochnik po tyazhelym litofilnym redkim metallam [Geological reference book on heavy lithophile rare metals]. Ed. by N.P. Laverov. Moscow, Nedra Publ., 1987. 438 p.

10. Hori H., Kobayashi T., Miyawaki R., Matsubara S., Yokoyama K., Shimizu M. Iwashiroite-(Y), $\mathrm{YTaO}_{4}$, a new mineral from Suishoyama, Kawamata Town, Fukushima Prefecture, Japan. Journal of Mineralogical and Penological Sciences, 2006, vol. 101, pp. 170-177.

11. Huraiová M., Konečný P., Hurai V. Niobium mineralogy of Pliocene $A_{1}$-type granite of the Carpathian Back-Arc Basin, Central Europe. Minerals, 2019, vol. 9, no. 488, pp. 1-16.

12. Popova V.I., Popov V.A., Blinov I.A., Kotlyarov V.A., Kasatkin A.V., Shkoda R., Lebedeva S.M. New findings of rare minerals in pegmatites of Vishnevye Mountains in the Southern Urals. Mineralogy, 2019, vol. 5, no. 1. pp. 3-14. In Rus.

13. Novoselov K.L. Accessory niobium-tantalum minerals of the Aleisk granite massif (N-W Rudny Altay area). Bulletin of the Tomsk Polytechnic University, 2020, vol. 331, no. 2, pp. 38-44. In Rus.

14. Rafikov Ya.M., Yusupov R.G. Productivity and ore-bearing of granite-leucogranite complex in the rare earths, yttrium (chatkalkuramin continental boardland). National Geology, 2013, no. 1, pp. 59-69. In Rus.

15. Betekhtin A.G. Mineralogiya [Mineralogy]. Moscow, Gosgeolizdat Publ., 1950. 956 p

16. Fu-Yuan Wu, Xiao-Chi Liu, Zhi-Chao Liu, Ru-ChengWang, Lei Xie, Jia-MinWanga, Wei-Qiang Ji, Lei Yang, Chen Liuc, Gautam Prashad Khanal, Shao-Xiong He. Highly fractionated Himalayan leucogranites and associated rare-metal mineralization. Lithos, 2020, vol. 352-353, pp. 1-24.

17. Na-Xin Guoa, Zheng Zhaoa, Jian-Feng Gaob, Wei Chenc, DengHong Wanga, Yu-Chuan Chena. Magmatic evolution and W-SnU-Nb-Ta mineralization of the Mesozoic Jiulongnao granitic complex, Nanling Range, South China. Ore Geology Reviews, 2018, vol. 94 , pp. 414-434.

18. Gusev A.I. Typezation of pegmatite mineralization of Altai. Modern high technologies, 2014, no. 3, pp. 93-97. In Rus. 
19. Gusev A.I. Rare earth elements pegmatites of west part AltaiSajan folded area. Izvestiya AO RGO, 2015, no. 3(38), pp. 16-24. In Rus.

20. Savelyeva V.B., Bazarova E.P., Khromova E.A., Kanakin S.V. Redkometalnye mineraly $\mathrm{v}$ porodakh Kagutinskogo redkometallnogo mestorozhdeniya [Rare minerals in the rocks of the

Information about the authors
Katugin rare metal deposit, east Transbaikalia: Behavior of lanthanides and $\mathrm{Y}$ during crystallization of an F-saturated agpaitic melt]. Geology of Ore Deposits, 2017, vol. 146, no. 4, pp. 1-21. In Rus.

Received: 9 June 2021.

Konstantin L. Novoselov, Cand. Sc., associate professor, National Research Tomsk Polytechnic University. 